\title{
Free burgher women in the eighteenth century and the quest for status
}

\author{
Liza-Mari Oberholzer*
}

\begin{abstract}
As the burgher population at the Cape of Good Hope developed over the course of the eighteenth century, identity and status became increasingly important. Material culture, used for the purpose of personal adornment, was a prominent means of demonstrating social positions. This article explores the role of burgher women in Cape Dutch society, and demonstrates how this group used clothing as markers of distinction to denote their social position. By using objects such as clothing, free burgher women managed to create an association with a particular status group, and in so doing increased their own social importance. Association with the higher echelons of society was particularly important to a group of nouveaux riche burghers who had started to intermarry with the VOC official elite. This article argues that burgher women in perpetuating the notion of "conspicuous consumption" used clothing and personal adornment as a means of establishing and in some instances increasing their status and social importance in Cape Dutch society.
\end{abstract}

Key words: Conspicuous consumption; burgher women; status; material culture; Cape of Good Hope; VOC; gender.

\section{Opsomming}

Namate die burgherlike bevolking aan die Kaap van Goeie Hoop in die loop van die agtiende eeu ontwikkel het, het identiteit en status toenemend belangrik geraak. Materiële kultuur, en veral die gebruik van persoonlike versiering, was 'n prominente wyse om sosiale posisies en status uit te beeld. Hierdie artikel verken die rol van burger vroue binne Kaaps-Hollandse samelewing, en demonstreer hoe hierdie groep klere as merkers van onderskeiding gebruik het om hul sosiale posisie aan te dui. Deur die gebruik van voorwerpe soos klere het vryburger vroue daarin geslaag om 'n verbintenis met 'n bepaalde status groep te skep, en het sodoende hul eie sosiale posisie beklemtoon en selfs verhoog. Interaksie met die hoër range van die samelewing

\footnotetext{
Liza-Mari Oberholzer is based in Pretoria and is enrolled for her $\mathrm{PhD}$ in the Department of Historical Studies at the University of Johannesburg. Her current research explores the changing relationships of the late eighteenth and early nineteenth-century Cape elite, through the tumultuous change in government, which was due in part to the Napoleonic wars. Her email address is: lizamari.coetzee@gmail.com
}

How to cite this article: L. Oberholzer, "Free burgher women in the eighteenth century and the quest for status", Historia, 62, 1, May 2017, pp 1-18. http://dx.doi.org/10.17159/2309-8392/2017/v62n1a1

Copyright: (CThe Author(s). Published under a Creative Commons Attribution Licence. 
was veral belangrik vir die groep nouveaux riche burgers wat begin het om ondertrou met die amptelike VOC elite. Hierdie artikel voer aan dat burger vroue klere en persoonlike versiering as ' $\mathrm{n}$ middel gebruik het om hul status en sosiale belangrikheid te beklemtoon en selfs te laat toeneem binne die koloniale samelewing.

Sleutelwoorde: Opsigtelike verbruik; burgervroue; status; materiële kultuur; Kaap de Goede Hoop; VOC; geslag.

\section{Introduction}

European expansion and global interaction in the early modern period (c. 1500-1800) resulted in a new world in which previously isolated parts of the globe came into contact. The interaction between different cultural and social groups in contact situations led to the development of new social identities. In this process, both belonging and belongings play an important role - belonging to certain groups and using one's belongings to portray your perception of belonging. ${ }^{1}$ This study is undertaken within the context of the "new cultural history" which has been especially influential in the study of the early modern period over the last three decades. Cultural history has as its aim the uncovering of past experience; it is interested in the lived reality of ordinary individuals, particularly their creation of meaning. Thus, cultural historians are interested in performance - whether linguistic, behavioural or ritual and the symbolic meanings people attached to this. ${ }^{2}$ The study of material culture and consumption fits in well within this paradigm.

The ideas of cultural history, especially as it relates to material culture and social identity, have also recently influenced the development of the historiography of the VOC Cape. ${ }^{3}$ One way in which this has been done for the early Cape is through the study of material culture. Emanating from the Historical Archaeological Research Group at UCT in the 1990s, various historians have used household inventories to trace the impact of colonialism on the lived reality of individuals. ${ }^{4}$ Scholars such as Antonia Malan have produced a series of articles using a combination of analysing household inventories and archaeological data to discover more about issues relating to consumption and identity. ${ }^{5}$ More recently, inspired by this material turn and the

1. L.J. Mitchell, Belongings: Property, Family, and Identity in Colonial South Africa (Columbia University Press, New York, 2009).

2. M. Rubin, "What is Cultural History Now?", in D. Cannadine (ed.), What is History Now? (Palgrave Macmillan, Houndmills, 2003), pp 80-94.

3. N. Worden, "New Approaches to VOC History in South Africa", South African Historical Journal, 59, 2007, pp 3-18.

4. M. Hall, Archaeology and the Modern World: Colonial Transcripts in South Africa and the Chesapeake (Routledge, London and New York, 2000).

5. A. Malan, "The Material World of Family and Household: The Van Sitterts in EighteenthCentury Cape Town", in L. Wadley (ed.), Our Gendered Past: Archaeological Studies of Gender in Southern Africa (Wits University Press, Johannesburg, 1997), pp 273-301; and A. Malan, "Beneath the Surface, behind the Doors: Historical Archaeology of Households in mid-Eighteenth Century Cape Town", Social Dynamics, 24, 1 (1998), pp 88-118. 
international historiographic move to cultural history and the study of identity, VOC historians have begun to investigate the social identities of various groups at the early Cape that have hitherto been ignored, such as the free burghers. In these studies material culture is often used to gain insight into the identities of such groups. ${ }^{6}$

Although our understanding of various social groups and the role of material culture in their lives has therefore been much improved, there still remain some gaps, which this study seeks to address. Firstly, although historical archaeologists have investigated a variety of material culture objects, the role of clothing at the Cape has received relatively little attention. Martin Hall only provides a brief discussion of the links between clothing and status, mostly in relation to the 1755 sumptuary laws. The second major gap which exists is the relative neglect of women in the existing historiography. Although VOC historians have looked at cultural history and the lived realities of a range of social groups at the Cape in recent years, such as the essays in the volume edited by Nigel Worden, Cape Town between East and West (2012), there is little sustained new research. Not a single chapter in this publication is dedicated to women, although some VOC historians do consider women in their larger analyses. ${ }^{7}$ In particular, the unique role of elite burgher women, who acted as regulators of society and were active participants in colonial culture during this period, has not been stressed sufficiently. Burgher women played an important role in both the establishment of Dutch norms and culture at the Cape of Good Hope and in helping to create new burgher elites. As such, this article seeks to investigate how the conspicuous consumption of items of personal adornment, particularly clothing, were used by burgher women to assert or reassert their status.

\section{The formation of a burgher elite in Cape colonial society}

The original plan of the VOC for the settlement at Table Bay did not include the establishment of a free burgher population but the first exception to this was made by Jan van Riebeeck when he allowed the wife of the Company gardener to open a tavern. ${ }^{8}$ This was the first step in establishing the free burgher population at the Cape which eventually settled into one of two roles. The first was the urban free burghers who made a livelihood from the ships that called in the bay; and the other was free burghers who farmed in order to provide the VOC with fresh produce needed to restock passing ships. By the 1730s, Otto Mentzel, a German soldier living at the Cape, divided the free burgher population into four classes according to their economic well-being. This first class, and the most important for this discussion, comprised members of the free

6. See for example the various essays in N. Worden (ed.), Contingent Lives: Social Identity and Material Culture in the VOC World (Historical Studies Department, Cape Town, 2007).

7. Worden (ed.), Contingent Lives; and N. Worden (ed.), Cape Town between East and West: Social Identities in a Dutch Colonial Town (Jacana Press, Johannesburg, 2012).

8. D.B. Bosman and H.B. Thom (eds), Daghregister Gehouden by den Oppercoopman Jan Anthonisz van Riebeeck, Volume 1, 1652-1656; Volume 2, 1656-1658 (A.A. Balkema, Cape Town, 1958), p 39. 
burgher population who managed to live comfortably in Cape Town while also possessing a farm, or various farms in the countryside. ${ }^{9}$

The class of free burghers or the burgher elite was divided into two streams, the urban elite and the landed elite. The growth of viticulture and grain production between 1720 and 1750 and subsequent territorial expansion led to the growth of burgher elites with an agrarian base. Robert Ross argues that these enterprising farmers, who managed to bring more land under production, are the ones who became prosperous by the 1780s and who attracted much attention and comment from their contemporaries. In 1783, Commissioner Hendrik Breton wrote of these farmers:

... on various farms that I expressly visited, I found a far from simple life, and nothing except signs of prosperity, to the extent that in addition to splendour and magnificence in clothes and carriages, the houses are filled with elegant furniture and tables decked with silverware and served by tidily clothed slaves. ${ }^{10}$

The second group of burgher elites consisted of the urban-based free burgher. The retail of alcohol and meat was regulated by the VOC which issued pachten (alcohol and meat leases) yearly. These pachten were bought by the highest bidder who then acquired the right to retail various types of alcohol or meat. The alcohol trade was very successful and profitable and served to create a relatively stable class of wealthy burghers who were urban-based but often with extensive interest in agriculture. Between 1680 and 1795 the VOC sold alcohol pachten to 198 individuals, a substantial number of people who formed a large part of the urban elite. ${ }^{11} \mathrm{~A}$ second, though slightly less lucrative trade, was the meat pachten for the supply of meat to the VOC, yet by the eighteenth century it was obvious that the alcohol pacht was easier and more lucrative since it did not require as much start-up capital. ${ }^{12}$

Although some historians have suggested that these two groups of burgher elites, i.e. the urban elite and landed elite, developed along separate lines and are therefore mutually exclusive, historians such as Gerald Groenewald and Gavin Williams have recently argued that the situation was more complex. According to Williams the term "landed gentry", which has been used to refer to this group of agrarian elite burghers, should be discarded because it is not applicable to the situation at the Cape. There are many examples of members of the burgher elite who did not necessarily acquire (all) their wealth through farming activity. It is true that many of these wealthy entrepreneurs diversified their property holding into a number of farms, but this was not their initial source of wealth. Williams argues that the richest farmers at the Cape accumulated wealth not only from trade, Company contracts, the pacht

9. R. Ross, "The Rise of the Cape Gentry", Journal of Southern African Studies, 9, 2 (1983), pp 193-217.

10. Cited in S.D. Naude, "Willem Cornelis Boers", Archives Year Book for South African History, 13, 2 (1950), p 413.

11. G. Groenewald, "Een Dienstig Inwoonder: Entrepreneurs, Social Capital and Identity in Cape Town, c. 1720-1750", South African Historical Journal, 59, 1(2007), p 4.

12. Groenewald, "Een Dienstig Inwoonder", p 5. 
system and entrepreneurial enterprises - but also from their marriages to wealthy widows who had inherited property. ${ }^{13}$

Some of the individuals originally seen as prime examples of the landed gentry, like Hendrik Eksteen, first made their fortune through commercial activities such as alcohol pachten. Thereafter he invested in land and slaves, eventually acquiring seven farms; six town properties; seven loan farms; and 100 slaves. ${ }^{14}$ Therefore it is not always possible to distinguish between those burghers categorised as "gentry" and "urban elite" respectively, because these groups were not mutually exclusive. By the late eighteenth century, members officially belonging to the so-called "landed gentry" also held pachten, such as in the case of the De Nijs family as discussed by Groenewald. ${ }^{15}$

By the mid-eighteenth century, colonial society at the Cape of Good Hope had become settled into a social hierarchy in which the VOC senior officials were at the top, followed by the lower ranking VOC employees, the burgher elite, other burghers, and finally, an underclass that consisted of free blacks, soldiers, sailors and slaves. Economic growth eventually led to the development of a relatively stable class of burgher elite at the Cape by the end of the eighteenth century. As the free burgher population grew in size and became more prosperous, the competition between VOC officialdom and the free burgher elite increased because they competed on issues of precedence and status. ${ }^{16}$ Some social fluidity remained despite the hierarchical divide - marriages could still change social status. As has been convincingly argued by Groenewald, intermarriage between these groups, especially between the free burgher elite and the VOC official elite, became increasingly common as the century wore on. ${ }^{17}$ Because a woman's social status was directly linked to that of her father (if unmarried) or that of her husband (if married), identity and social status were not fixed and could change with subsequent marriages. Because of this, some fluidity remained between the burgher underclass, the burgher elites and VOC officials, particularly through the vehicle of marriage. In addition, because of the relatively small size of the colonial population at the Cape, interaction between these groups was common. This context, where upward mobility remained possible, led to an increasing emphasis on the use of

13. G. Williams, "Who, Where and When were the Cape Gentry?", Economic History of Developing Regions, 28, 2(2013), p 97.

14. G. Groenewald, "An Early Modern Entrepreneur: Hendrick Oostwald Eksteen and the Creation of Wealth in Dutch Colonial Cape Town, 1702-1741", Kronos, 35, 1 (2009), p 9.

15. G. Groenewald, "Dynasty Building, Family Networks and Social Capital: Alcohol, Pachters and the Development of a Colonial Elite at the Cape of Good Hope, c. 17601790", New Contree, 62 (2011).

16. W. Dooling, "The Making of a Colonial Elite: Property, Family and Landed Stability in the Cape Colony, c. 1750-1834", Journal of Southern African Studies, 31, 1(2005), pp 147-162.

17. Groenewald, "Dynasty Building". 
status symbols to claim "belonging" to certain groups. ${ }^{18}$ In this, burgher women and the ways they presented themselves through clothing and other adornments, played a crucial role.

\section{Elite identity and personal adornment}

The consumption of material goods was a way in which newly formed societies attempted to either affirm or re-affirm their identity, or a way in which individuals could attempt to claim a different identity. ${ }^{19}$ Claiming a new or different identity was particularly prevalent in colonial societies where there was a high social mobility. Because the consumption of certain material goods could denote association with a certain status group, material goods became status symbols that were associated with a particular segment or group in that society. In colonial societies this consumption was much more effective in allowing the individual to move to another status group than it was in socially rigid societies that were, for example, found in Europe. ${ }^{20}$

During the early modern period, material culture functioned increasingly as a symbol of identity and status rather than ways of fulfilling basic needs. One such material possession, which was particularly relevant for demonstrating social position, was clothing. This included all forms of personal adornment, including jewellery, accessories, footwear and, most commonly, actual items of clothing. Clothing was used as a visual form of consumption and could signify an individual's position in the public sphere at a single glance. Because clothing was so openly conspicuous, social elites used fashion as a way to differentiate themselves from those who did not belong to the elite. According to Ross, clothing has been used as a marker of identity and status throughout history, serving as a visual source of information for identifying an individual's position in society. ${ }^{21}$ The effect of global European expansion resulted in an increase in the importance of clothing as a marker of distinction and increased emphasis was placed on its importance. In Dutch colonial society, the use of personal adornment to denote an individual's position in society was demonstrated by a series of sumptuary laws that were codified in 1755 by the VOC government in Batavia, through which the VOC attempted to prevent free burghers from becoming too ostentatious - and thereby threatening the social power of the Company. These laws attempted to regulate the way status symbols were used by the different social groups; they were imposed to control who held the perceived social power. ${ }^{22}$

18. G. Groenewald, "A Class Apart: Symbolic Capital, Consumption and Identity among the Alcohol Entrepreneurs of Cape Town, 1680-1795", South African Journal of Cultural History, 26, 1(2012).

19. Mitchell, Belongings: Property, Family, and Identity, especially chapter 5.

20. R. Ross and A. Schrikker, "The VOC Official Elite", in Worden (ed.), Cape Town between East and West, p 40.

21. R. Ross, Clothing: A Global History (Polity Press, Cambridge, 2008).

22. L. Coetzee, "Gender and Social Identity at the Cape of Good Hope, 1652-1795", MA dissertation, University of Johannesburg, 2015. 


\section{The role of burgher women in elite formation}

Writing about Cape society, Hall claims that "the emergent elite of the colonial countryside formed a web of economic and social relationships around connections between women who were marked out by their claim to racial purity and superiority." 23 Hall suggests that women formed an integral part of early colonial society at the Cape, serving as the stabilising factor in a society that was ever-changing due to the influx of immigrants from Europe and elsewhere. Ann Stoler has argued that another important characteristic of women in the colonial context was the fact that European women were agents of imperial culture in their own capacity, even if they did not have any political position. Therefore, these women, either born in the colonies and raised with Dutch values, or newly settled within the colonies, acted as "regulators of culture" in society, whether it be regarding economic, social or any other values important to them. Therefore, the arrival of larger numbers of European women coincided directly with processes of embourgeoisement in colonial society. ${ }^{24}$ This means that European women effectively became regulators of social status and hierarchy, establishing what and who was socially acceptable. As such, they exercised a significant influence on social practices in the colonies.

The importance of women in Cape society, especially concerning economic relationships, can be seen in the work of Groenewald on the alcohol pachters. Groenewald argues convincingly that male immigrants often used marriages to Capeborn women to gain financial and social capital, which was then used for the expansion of their entrepreneurial interests. ${ }^{25}$ These marriages to Cape-born women allowed immigrant men to tap into an existing network of social capital - that is, the support an individual could gain from those in their social circles, their friends and family, and which could then be translated into financial gain. ${ }^{26}$ By marrying a Cape-born woman, an immigrant man also married into an existing social circle. Women also played a significant role in the establishment of family networks within the VOC world. As in Batavia, Colombo and other VOC outposts, women played an important role in establishing ties between the rooted (local burgher elite) and mobile (VOC official) elites. Therefore, because of the role of women in early colonial society at the Cape, these two groups were never mutually exclusive, although a distinction did indeed exist. For this reason, in addition to those mentioned above, Cape burgher women were essential to the development of an elite burgher class. The same process also occurred on the eastern frontier of the colony with marriage strategy being used to create family dynasties and gain control over land and resources. ${ }^{27}$

23. M. Hall, "The Secret Lives of Houses: Women and Gables in the Eighteenth-Century Cape", Social Dynamics, 20,1(1994), p 3.

24. A.L. Stoler, "Making Empire Respectable: The Politics of Race and Sexual Morality in Twentieth-Century Colonial Cultures", in A. McClintock, A. Mufti and E. Shohat (eds), Dangerous Liaisons: Gender, Nation, and Postcolonial Perspectives (University of Minnesota Press, Minneapolis, 1997) p 351.

25. Groenewald, "Dynasty Building", p 23.

26. Groenewald, "Een Dienstig Inwoonder", p 15.

27. Groenewald, “Een Dienstig Inwoonder", p 15. 


\section{Burgher and VOC elite in colonial Cape Town}

During the VOC period, burgher women were part of a culture that was clearly defined according to rank and social status. This social hierarchy was evident from the celebrations of special occasions, such as the birthday of the Prince of Orange or that of the governor. Prominent free burghers would take part in the celebrations alongside high-ranking VOC officials. ${ }^{28}$ The upper echelons of the burgher elite therefore seem to have been, if not equal, close in status to the VOC official elite, sharing in the official festivities and even dining at the governor's table. Mentzel writes of one of these events, held on 20 October each year:

... when the burgher mounted and infantry forces have completed their annual week of military exercises. On the last day the burgher companies draw up in front of the Castle gate, which is barred, and each Company fires three musketry salvoes. The salvoes are answered by cannon shots from the Castle. The Companies then draw off and the men separate until the next year. In the evening all the burgher officers are entertained by the Governor, and to this banquet, as well as to the earlier one, all local people of distinction are invited... ${ }^{29}$

Mentzel goes on to explain that at the governor's table "there would always be present some of the senior officials or some prominent burghers", ${ }^{30}$ indicating that some of the members of the free burgher society managed to cross social lines. Members of the free burgher elite, such as the burgher councillors and their wives, were also received at the Castle for New Year's festivities. The association between the VOC elite and elite free burghers was further encouraged by dances and receptions held at the homes of some of the wealthier inhabitants of the town. A particularly prominent example of the intermarriage between the VOC official elite and members of the burgher elite was the marriage between Governor Ryk Tulbagh and the sister of Hendrik Swellengrebel. ${ }^{31}$

Late in the eighteenth century, during a period when the inhabitants of Cape Town were known for their imitation of European culture and fashions, Le Vaillant refers to this association when he writes of the Cape:

Almost all the women play the harpsichord; it is their only talent. They like to sing and are mad about dancing; thus rarely a week passes without several balls taking place. The officers of ships calling in the bay often give them the occasion for

28. N. Worden, "Space and Identity in VOC Cape Town", Kronos: Journal of Cape History, 25 (1998/1999), p 12; and R. Ross, Status and Respectability in the Cape Colony, 17501870: A Tragedy of Manners (Cambridge University Press, Cambridge, 2004), pp 19-26.

29. O.F. Mentzel, Life at the Cape in the Mid-Eighteenth Century: Being the Biography of Rudolph Siegfried Allemann (Van Riebeeck Society, Cape Town, 1919), p 112 (emphasis added).

30. O.F. Mentzel, A Geographical-Topographical Description of the Cape of Good Hope, part 2 (Van Riebeeck Society, Cape Town, 1925), p 100.

31. G. McCall Theal, History of South Africa, 1691-1975 (Sonnenschein \& Co., London, 1888), pp 137-183. 
offering a ball. When I arrived, the Governor used to give a public ball once a month, and the people of importance followed his example. ${ }^{32}$

It becomes clear, then, that there were several instances where the VOC elite and the burgher elite could interact socially at the Cape; a contributing factor being the small size of the settlement. Another social situation where people of different statuses could interact was provided by weddings. Mentzel refers to them as being "very mixed affairs; higher and subordinate officials as well as common burghers meet on the same plane". ${ }^{33}$ People of different social strata also interacted through being members of the same church congregation. The interaction between VOC officials and the free burgher elite is evident in the fact that the church council at the Cape consisted of both high VOC officials and members of the free burgher elite. According to Biewenga, as many as 50 percent of the church council comprised free burghers who would serve for a two-year period before they were replaced by a democratic nomination which was forwarded to the Council of Policy. The latter body, however, had the final say in the appointment of a new member of the church council. ${ }^{34}$ Social ties between members of the VOC official elite and the burgher elite would either be established by their interaction as members of the church council or would be perpetuated by the appointment of friends or family members by the Council of Policy.

Friendships also appear to have spanned the social divide. Mentzel testifies to this, stating that "... girls of the best families will, before their marriage ... [form close ties of friendship] with respectable girls of much more lowly origin". ${ }^{35}$ Yet the same seems not to have been true of married women; in fact, Mentzel rather suggests that married women were the members of society who were most conscious of their social status. He writes: “... formality governs the interchange of the ladies of the town. Among them social distinctions are sharply graded; pomp and circumstance play a leading role in determining the rules of etiquette." 36 Only a little further he adds: "... unwritten laws define the attitude of women to women on different social levels". ${ }^{37}$

It becomes clear, therefore, that although on one level there was much interaction between, firstly, the VOC elite and burgher women of different social standing, often these same women were the regulators of this interaction, determining the way the interaction took place through strict protocol. The same protocol did not apply to an unmarried woman who could still acquire either a higher or a lower status through marriage. For this reason, I will look mainly at married women in the following case studies because their social status became relatively fixed upon marriage although, as in the case of Wilhelmina de Wit, that too could alter upon a subsequent

32. F. Le Vaillant, Travels into the Interior of Africa via the Cape of Good Hope (Van Riebeeck Society, Cape Town, 2007), p 17.

33. Mentzel, Geographical-Topographical Description, part 2, p 105.

34. A.W. Biewenga, "Kerk in Een Volksplanting: De Kaap de Goede Hoop", in Schutte, G.J. (ed.), Het Indisch Sion: De Gereformeerde Kerk onder de Verenigde Oost-Indische Compagnie (Uitgeverij Verloren, Hilversum, 2002), p 208.

35. Mentzel, Geographical-Topographical Description, part 2, p 105 (emphasis added).

36. Mentzel, Geographical-Topographical Description, part 2, p 107.

37. Mentzel, Geographical-Topographical Description, part 2, p 107. 
marriage. Through the following case studies, I explore the ways women of the early Cape burgher society used their clothing as a means of displaying their social status.

\section{Josina van Dam: Entrepreneur and business woman}

The case of Josina van Dam is particularly revealing when considering the development of Cape society and the role played by women in society. Josina van Dam was one of very few women who possessed an alcohol pacht in her own right. Groenewald states correctly that although the figures of women officially participating in the alcohol trade at the time were low (in fact, fewer than five percent of all pachters at the Cape were women), one should take into account that women participated widely in the trade, although not necessarily in their own names. ${ }^{38}$ Many women were involved in the running of the business although their position was not officially recognised in contracts and other legal documents. Josina van Dam was exceptional in that she was in possession of five alcohol pachten in the years 1730 and 1731, all in her own name. Not only did this make Josina van Dam a remarkable burgher woman, but the suggestion is that she was an able entrepreneur, being one of only five pachters who were in possession of three to five alcohol pachten in the 1730 s. $^{39}$

That Josina van Dam was a very wealthy woman cannot be disputed. The alcohol pacht was an extremely lucrative trade, so much so, that burghers were prepared to pay huge amounts to enter it. On 8 July 1731, Josina married her second husband, Jan van der Swijn. He had arrived as a Dutch immigrant from The Hague aboard the ship Wilplaarsdijk in 1723 as an adelborst (midshipman). His marriage to Josina van Dam was particularly beneficial to him because she was the widow of the wealthy alcohol pachter, Jan Jacob Stokvliet and at that time Josina already held various pachten in her own name. In addition, the marriage was especially important for Van der Swijn because of the social capital Josina possessed in the social and business circles of the alcohol pachters and allowed for the couple's own economic advancement. ${ }^{40}$ Josina's social connections established her husband, Jan van der Swijn and put him in a position to further his own social and entrepreneurial ambitions. Van der Swijn became a largescale alcohol pachter following Josina's death: he owned 19.67 alcohol pachten between 1732 and 1747, averaging 1.31 pachten per year. The exploitation of these alcohol pachten made Josina van Dam (initially in her own capacity) and her husband exceedingly wealthy; wealthy enough to form part of the urban elite, a group of people whose ostentations use of conspicuous goods would eventually cause great concern for the VOC government. ${ }^{41}$

The inventories of both Josina van Dam and that of her husband give an indication of the luxurious life they enjoyed. Van der Swijn's inventory suggests that he

38. Groenewald, "Een Dienstig Inwoonder", p 9.

39. Groenewald, "Een Dienstige Inwoonder", p 9.

40. A. Malan, "The Cultural Landscape", in Worden (ed.), Cape Town between East and West, p 20.

41. G. Groenewald, "Entrepreneurs and the Making of a Free Burgher Society", in Worden (ed.), Cape Town between East and West, p 55. 
was conscious of how he appeared to the public; that he made use of highly conspicuous goods in order to gain recognition and social prestige. ${ }^{42}$ It is likely that he would have expected his wife to display similar symbols of social prestige. By examining Josina van Dam's own inventory, which was compiled upon her death in 1732, we can gain important knowledge of the role of women and their clothing in establishing and maintaining status in the Cape. The details of her estate suggest that van Dam was not only well dressed and well adorned with jewellery, but that her possessions would have rivalled many of those belonging to women of the VOC elite. Josina van Dam's inventory contains the following pieces of jewellery:

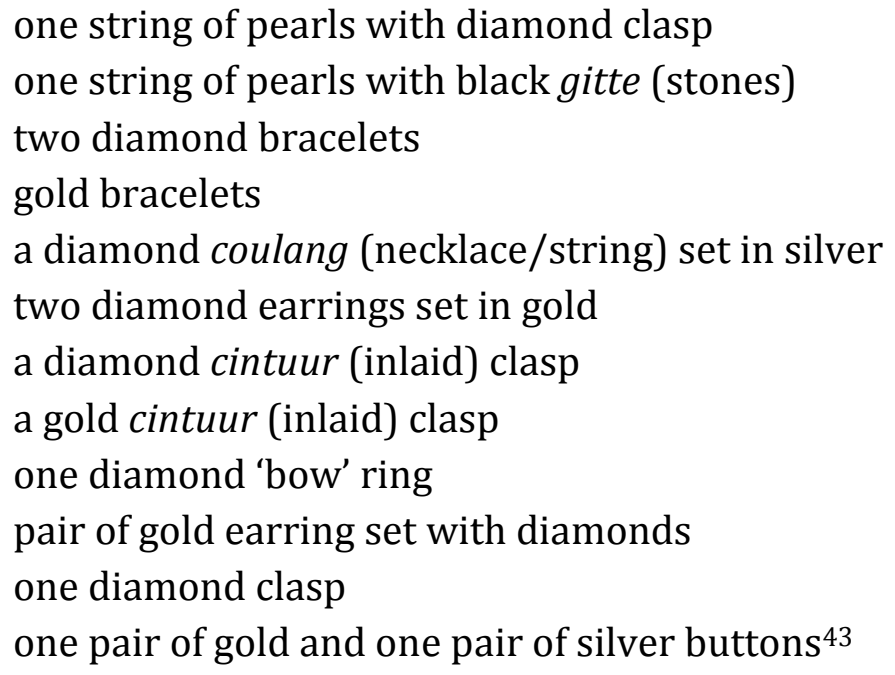

But what is rather more impressive than the individual pieces is the price some of these pieces fetched on the auction following her death. Although the amount of jewellery is not exceedingly extravagant for the time, there is no question as to the value and quality of these items. The string of pearls with a diamond clasp, for instance, sold for 149.2 rixdollars at Van Dam's estate sale. ${ }^{44}$ This is the highest amount fetched for a string of pearls in the auction lists ranging from 1691 to 1748 - auction lists which include prominent women such as Debora de Koning who was one of the wealthiest women of her day 45 . Josina van Dam's pearls were therefore the most expensive string of pearls sold at auction for 57 years. No doubt the value of the pearls was reflected in the way they appeared, which in itself suggests the prominence and wealth of the urban elite. The wealth of the burgher elite would undoubtedly have been emphasised by the conspicuous use of such an expensive item, which in turn would have reflected the social status of both Josina and that of her husband.

It is Josina's clothing that is of particular interest, because her clothing is an indicator of her status. Although Josina was a business woman, her clothing rather reflects the life of an idle woman of high status. Her inventory lists the following items:

42. This paragraph is based largely on: Groenewald, "Entrepreneurs and the Making of a Free Burgher Society", p 54.

43. Cape Town Archive Repository, Transcription of the Estate Papers of the Cape of Good Hope (hereafter TEPC), MOOC 8/5.110.

44. TECP, MOOC 10/4.116.

45. TEPC, MOOC 10/4.110 and MOOC 10/4.116. 


\author{
41 women's dresses \\ one women's corset \\ one women's bonnet \\ 3 women's balijne dresses \\ 11 pairs of women's silk gloves \\ one unfinished linen women's dress \\ 29 women's shirts \\ 20 women's aprons \\ 3 women's shirtdresses \\ 12 handkerchiefs \\ miscellaneous women's caps and handkerchiefs \\ 4 fans $^{46}$
}

Unfortunately, her inventory does not include a description of the materials used for the making of her dresses; nor were they sold on auction, so we do not learn the value of the individual items. Nevertheless, the sheer number of the dresses she owned is an indication of Van Dam's social status. Her inventory includes 45 dresses (if one counts the unfinished dress); a number that was excessive at the time, when one compares it to the dresses owned by Anna Fothergill, who was effectively the woman with the second highest social status at the Cape - and who belonged to the VOC official elite. Fothergill's inventory, compiled in 1764 (some 32 years later), includes 38 dresses, and this at a time when the Cape was experiencing large-scale economic growth. Fothergill's tally of dresses is rarely paralleled during the colonial period. ${ }^{47}$ Therefore, one can draw the conclusion that the urban burgher elite was attempting to affirm its position as part of the social elite, even contesting social position through the use of extravagant amounts of clothing and by wearing expensive items of personal adornment. These material items became a means of contesting accepted norms of social importance and challenged the existing assumption that the VOC official elite included the most prominent members of Cape society. Van Dam obviously chose to use her money in such a way as to display herself as a prominent woman of exalted social status.

\title{
Wilhelmina de Wit
}

The case of Wilhelmina de Wit further illustrates how women in free burgher society used their clothing as a means of portraying their social position in Cape society. Wilhelmina Adriens de Wit was born in about 1670 in Rotterdam in the Netherlands. As an orphan girl, she was sent to the Cape in 1688 as part of an attempt to increase the number of European women at the Cape. ${ }^{48}$ Once there, Wilhelmina de Wit was first

\footnotetext{
46. TEPC, MOOC 8/5.110.

47. L. Coetzee, "Fashion and the World of the Women of the VOC Official Elite", New Contree, Special edition, 73(2015), p 77.

48. J.A. Heese, "Die Hollandse Weesmeisies", Familia, 3 (1976). Wilhelmina and her seven orphan companions were sent to the Cape following requests made by Jan van Riebeeck in 1659, and Simon van der Stel in 1685, that the Heeren XVII should send between 20
} 
married to Diedelhof Biebault. Records state that they both stood witness to the baptism of their first child, Hendrik Biebault in 1690, only two years after her arrival at the Cape. Wilhelmina's first husband was very poor and after his death in 1695, he left only meagre possessions to his wife and three children. ${ }^{49}$ Besides a house, which according to the estate account was very run down, and one slave, the family was only left with:

\author{
1 old horse \\ 4 pots, 2 copper kettles \\ some tin items \\ one pistol \\ old bedding \\ old kitchenware \\ one old kist \\ one old table \\ 20 teacups and saucers ${ }^{50}$
}

These possessions indicate that the family was by no means well off, but Wilhelmina de Wit's life is an indication of how marriage could change the socioeconomic status of a woman at the Cape. Sometime before 1700, she married Jacob Pleunis, for in 1700 a son, Johannes Pleunis, was born to the couple. ${ }^{51}$ Her second marriage must have been very different from the circumstances of the first, if one is to judge from the numerous luxury items listed in her inventory 27 years later. De Wit's estate inventory shows how extravagantly the elite of burgher society dressed at the time. Indeed, many of the items included in her inventory are the very same items that sumptuary legislation later attempted to regulate.

30 chintz dresses

2 woollen dresses

7 silk dresses

2 silk samaaren (dresses)

20 women's shirts

90 linen handkerchiefs

4 women's caps with lace

and 40 marriageable girls to the Cape, and that these girls should be able to assist in the farming activities of their prospective husbands.

49. TEPC, MOOC 8/1.14.

50. TECP, MOOC 8/1.14.

51. According to J. Hoge, "Personalia of the Germans at the Cape, 1652-1806", in Archives Year Book for South African History (Government Printer, Cape Town, 1946), Jacob Pleunis was originally from Orsoy and was born in 1662. Initially he is listed as a house carpenter and later as a deacon. He had a farm in the early 1700s in Banghoek, Stellenbosch. In 1710 his wife applied for a divorce because he had mistreated her often, but they were not divorced and at the time of her death in 1727 she is still listed as his wife. Cited from: "The First 50 Years Project", http://www.efamily.co.za/ffy/g7/p7846.htm. See also CJ 1123, p 121; G.R. no. 718, Test; CJ 1166; CJ 1070: 52; CJ 1812: 11. 
39 women's caps

14 halsjes (collars)

19 night caps

6 pairs of women's gloves

27 women's shirts

4 shirt dresses

23 aprons

18 handkerchiefs

3 silk handkerchiefs

2 halsjes (collars)

12 pairs of socks

1 women's cap

2 chintz robes

2 chintz dresses

1 rouw caper (black cape) ${ }^{52}$

Her inventory includes not only numerous items of clothing, but many are items of extremely high value, such as seven silk dresses. Silk was only worn by very wealthy burghers and members of the VOC elite. Silk was in fact such a prized material for clothing that the 1755 sumptuary legislation regulated the use of silk in making women's clothing. This legislation determined that silk dresses were the reserve of the wives of members of the VOC who held a position of junior merchant or higher. ${ }^{53} \mathrm{De}$ Wit's dresses would have been both expensive and conspicuous items in the eighteenth century. Besides the seven silk dresses inventoried, Wilhelmina de Wit was also in possession of 32 chintz dresses and two woollen dresses. The clothing included in her inventory is particularly excessive for the relatively early stage in the settlement of the Cape because the rapid economic growth of the later eighteenth century had not yet begun.

Besides the large number of dresses she apparently owned, there is also mention of 2 chintz japonnen which were initially used for inside wear as a robe, but later developed as a type of dress in its own right. ${ }^{54} \mathrm{~A}$ staggering number of caps and handkerchiefs are also listed in her inventory with a total of 45 caps, excluding her night caps, and 108 handkerchiefs. These caps and handkerchiefs were used as accessories at the time, greatly increasing the number of outfit combinations that Wilhelmina de Wit could wear. The lace trimming of the four caps mentioned in the inventory was also reserved for the wives and widows of the directors of outlying posts of the VOC. Therefore, had Wilhelmina lived later in the eighteenth century she would most probably have been fined for wearing these caps because her position as free burgher women would not have given her the status to wear these items. Besides the clothing, the inventory also included some jewellery, although these items are less

52 TECP, MOOC8/5.4.

53. S. du Plessis, "Pearls Worth Rds4000 or Less: Reinterpreting Eighteenth Century Sumptuary Laws at the Cape", ERSA Working Paper, no. 336, 2013, p 7.

54. H.C. Dibbits, Vertrouwd Bezit: Materiële Cultuur in Doesburg en Maassluis, 1650-1800 (Uitgeverij Nijmegen, Amsterdam, 2001), p 186. 
excessive for the day. They include 10 fans, some gold jewellery and a few buckles, among other items.

One of the most informative items in the inventory of Wilhelmina de Wit is the mention of five kiepersollen. The kiepersol was a parasol of sorts with an Eastern origin, and was a symbol of social status. ${ }^{55}$ The fact that Wilhelmina's inventory includes five of these suggests that they were used as an indicator of her social status and her position as one of the elite of the free burgher community. Although Wilhelmina died before the 1755 sumptuary legislation was enforced, there is a record of the regulation of the kiepersol as early as the seventeenth century. While this was probably not strictly applied, the re-issuing of this stipulation suggests that it had become a problem - many women who were not strictly speaking allowed to do so must have made use of this symbol of status. Article 30 of the 1755 sumptuary legislation limited the use of the kiepersol to those who possessed the status of junior merchant or higher, and stated that use of the kiepersol had to be regulated due to the large-scale infringement of this control measure. ${ }^{56}$ Wilhelmina's possession of these symbols of status suggests some form of contestation of accepted ideas of identity and status despite the use of a kiepersol by members of the burgher population who were not eligible to do so. Wilhelmina's infringement of this rule in itself is proof of the contestation of accepted societal norms of status and identity during this period.

In addition, Wilhelmina de Wit's later inventory, compared to that of her first husband, gives us an idea of how the social and economic position of an individual could change at the Cape. Having come to the Cape as an orphan girl, she managed to climb the social ladder of the small community to the extent that she became a wealthy burgher woman, with symbols of her social and economic status to boot. ${ }^{57}$ Considering Mentzel's remark that "money, not pedigree, is worshipped at the Cape", 58 the change in Wilhelmina's financial position over the years appear to have influenced her status in Cape burgher society. This gives credence to Mentzel's quote that the burghers at the Cape snubbed those who boasted of their lineage, saying instead: 'Segt niet wat gy geweest, maer segt wat gy tegens woordig zeyd. ${ }^{59}$ (We shall esteem you for what you are and not for what you have been.)

55. C.G. Botha, Social Life in the Cape Colony in the 18th Century (Cape Town, Juta, 1926), pp 61-62.

56. S.D. Naude (ed.), Kaapse Plakkaatboek, III (Cape Times, Cape Town, 1949), p 14.

57. The exact source of the Pleunis family's wealth is not known. After a few years of farming in Stellenbosch, they returned to Cape Town in the early 1710s. Perhaps Jacob Pleunis again took up his job as a carpenter. By the time of Wilhelmina's death, they owned a house in Table Valley and five slaves. Interestingly enough, their son joined the VOC administration, becoming a clerk (adsistent) in 1716 and being appointed as secretary of the Stellenbosch district in 1720. In 1722 he was promoted to the rank of boekhouder. See G.C. de Wet (ed.), Resolusies van die Politieke Raad V (1716-1719), (Government Printer, Cape Town, 1964), p 242 note 317.

58. Mentzel, Geographical-Topographical Description, part 2, p 115.

59. Mentzel, Geographical-Topographical Description, part 2, p 115. 
Whether it was a way of proclaiming her higher social status after her second marriage, or of competing with the elite members of the VOC during her lifetime, Wilhelmina de Wit's inventory is extremely informative in that it gives us a glimpse of how the possessions an individual owned could have an impact on her social position. Her clothing reflected her altered social status and served as an indication of how women at the VOC Cape gained their social identity through the use of personal adornment.

\section{Conclusion}

As society at the Cape developed over the span of the eighteenth century, burgher elites came to the forefront in society. The prosperity of this group increased and the steady process of intermarriage between the burgher elite and VOC officials impacted the social perceptions of the VOC elite. Members of the VOC elite were no longer revered office-bearers who were distinguished by their rank and took social precedence. Instead they became sons-in-law, brothers-in-law, uncles and so forth, occupying a familial position to many of the burghers. Because of this intermarriage the burgher elite and official elite at the Cape were not mutually exclusive. In addition, a woman's status was not fixed; colonial society became more fluid. It was of great importance that burgher women demonstrated their elite position in society. This demonstration of status and position played itself out in the use of conspicuous dressing and the use of items of personal adornment.

This new-found social prestige had a profound effect on the way burghers chose to present themselves to the outside world. Clothing in particular became a significant way of asserting one's social prestige. Furthermore, because burgher women acted as regulators of socially acceptable behaviour, the distinction between women of social importance and those who were socially below them was acted out through the dress and possessions of the socially influential. In this way, then, the newly wealthy, or

socially superior members of the burgher society attempted to distinguish themselves through the use of conspicuous consumption - this led to the acquisition and display of possessions with the intention of gaining social status, or of distinguishing themselves from those with less social standing.

\section{REFERENCES}

Botha, C.G., Social Life in the Cape Colony in the 18th Century (Juta, Cape Town, 1926). Biewenga, A.W., "Kerk in Een Volksplanting: De Kaap de Goede Hoop", in Schutte, G.J. (ed.), Het Indisch Sion: De Gereformeerde Kerk onder de Verenigde Oost-Indische Compagnie (Uitgeverij Verloren, Hilversum, 2002).

Bosman, D.B. and Thom, H.B., (eds), Daghregister Gehouden by den Oppercoopman Jan Anthonisz van Riebeeck, Volume 1, 1652-1656; Volume 2, 1656-1658 (A.A. Balkema, Cape Town, 1958).

Coetzee, L., "Fashion and the World of the Women of the VOC Official Elite", New Contree, Special edition, 73 (2015). 
Coetzee, L., "Gender and Social Identity at the Cape of Good Hope, 1652-1795", MA dissertation, University of Johannesburg, 2015.

De Wet, G.C (ed.)., Resolusies van die Politieke Raad V (1716-1719) (Government Printer, Pretoria, 1964).

Dibbits, H.C., Vertrouwd Bezit: Materiële Cultuur in Doesburg en Maassluis, 1650-1800 (Uitgeverij Nijmegen, Amsterdam, 2001).

Dooling, W., "The Making of a Colonial Elite: Property, Family and Landed Stability in the Cape Colony, c. 1750-1834", Journal of Southern African Studies, 31, 1(2005).

Du Plessis, S., "Pearls Worth Rds4000 or Less: Reinterpreting Eighteenth Century Sumptuary Laws at the Cape", ERSA Working Paper no. 336, 2013.

Groenewald, G., "A Class Apart: Symbolic Capital, Consumption and Identity among the Alcohol Entrepreneurs of Cape Town, 1680-1795", South African Journal of Cultural History, 26, 1(2012).

Groenewald, G., "An Early Modern Entrepreneur: Hendrik Oostwald Eksteen and the Creation of Wealth in Dutch Colonial Cape Town, 1702-1741", Kronos, 35 (2009). Groenewald, G., "Een Dienstig Inwoonder: Entrepreneurs, Social Capital and Identity in Cape Town, c. 1720-1750" South African Historical Journal, 59 (2007).

Groenewald, G., “Dynasty Building, Family Networks and Social Capital: Alcohol Pachters and the Development of a Colonial Elite at the Cape of Good Hope, c. 1760-1790", New Contree, 62 (2011).

Groenewald, G., "Entrepreneurs and the Making of a Free Burgher Society", in Worden, N. (ed.), Cape Town between East and West: Social Identities in a Dutch Colonial Town (Jacana, Johannesburg, 2012).

Hall, M., "The Secret Lives of Houses: Women and Gables in the Eighteenth-Century Cape", Social Dynamics, 20,1(1994).

Hall, M., Archaeology and the Modern World: Colonial Transcripts in South Africa and the Chesapeake (Routledge, London and New York, 2000).

Heese, J.A., “Die Hollandse Weesmeisies”, Familia, 3 (1976).

Hoge, J., "Personalia of the Germans at the Cape, 1652-1806", in Archives Year Book for South African History (Government Printer, Cape Town, 1946).

Le Vaillant, F., Travels into the Interior of Africa via the Cape of Good Hope (Van Riebeeck Society, Cape Town, 2007).

Malan, A., "The Cultural Landscape", in Worden N., (ed.), Cape Town between East and West: Social Identities in a Dutch Colonial Town (Jacana, Johannesburg, 2012).

Malan, A., "The Material World of Family and Household: The Van Sitterts in Eighteenth-Century Cape Town", in Wadley, L. (ed.), Our Gendered Past: Archaeological Studies of Gender in Southern Africa (Wits University Press, Johannesburg, 1997).

Malan, A., 'Beneath the Surface, behind the Doors: Historical Archaeology of Households in Mid-Eighteenth Century Cape Town”, Social Dynamics, 24, 1 (1998).

Mentzel, O.F., Life at the Cape in the mid-Eighteenth Century: Being the Biography of Rudolph Siegfried Allemann (Van Riebeeck Society, Cape Town, 1919).

Mentzel, O.F., A Geographical-Topographical Description of the Cape of Good Hope, part 2 (Van Riebeeck Society, Cape Town, 1925).

Mitchell, L.J., Belongings: Property, Family, and Identity in Colonial South Africa (Columbia University Press, New York, 2009). 
Naude, S.D. (ed.), Kaapse Plakkaatboek, III (Cape Times, Cape Town, 1949).

Naude, S.D., "Willem Cornelis Boers", in Archives Year Book for South African History, 13, 2 (Government Printer, Pretoria, 1950).

Ross, R., Status and Respectability in the Cape Colony, 1750-1870: A Tragedy of Manners (Cambridge University Press, Cambridge, 2004).

Ross, R., "The Rise of the Cape Gentry", Journal of Southern African Studies, 9, 2(1983).

Ross, R. and Schrikker, A., "The VOC Official Elite", in Worden, N. (ed.), Cape Town between East and West: Social Identities in a Dutch Colonial Town (Jacana, Johannesburg, 2012).

Ross, R., Clothing: A Global History (Polity Press, Cambridge, 2008).

Rubin, M., "What is Cultural History now?", in Cannadine, D. (ed.), What is History Now? (Palgrave Macmillan, Houndmills, 2003).

Stoler, A.L., "Making Empire Respectable: The Politics of Race and Sexual Morality in Twentieth-Century Colonial Cultures", in McClintock, A., Mufti, A. and Shohat, E. (eds), Dangerous Liaisons: Gender, Nation, and Postcolonial Perspectives (University of Minnesota Press, Minneapolis, 1997).

Theal, G. McCall., History of South Africa, 1691-1975 (Sonnenschein \& Co., London, 1888).

Williams, G., "Who, Where and When were the Cape Gentry?", Economic History of Developing Regions, 28, 2(2013).

Worden, N. (ed.), Cape Town between East and West: Social Identities in a Dutch Colonial Town. (Jacana, Johannesburg, 2012).

Worden, N., "Space and Identity in VOC Cape Town”, Kronos: Journal of Cape History 25 (1998/1999).

Worden, N., "New Approaches to VOC History in South Africa", South African Historical Journal, 59 (2007).

Worden, N. (ed.), Contingent Lives: Social Identity and Material Culture in the VOC World (Historical Studies Department, University of Cape Town, 2007). 